\title{
Immunosuppressive effect of arsenic trioxide on islet xenotransplantation prolongs xenograft survival in mice
}

\author{
Bin Zhao ${ }^{1,2}$, Jun-jie Xia ${ }^{3}$, Lu-min Wang ${ }^{3}$, Chang Gao ${ }^{3}$, Jia-li Li ${ }^{3}$, Jia-yin Liu², Qi-jun Cheng ${ }^{1}$, Chen Dai ${ }^{3}$, Qi-lin Ma ${ }^{2}$, \\ Zhong-quan $\mathrm{Qi}^{3}$ and Ben-hua Zhao ${ }^{1}$
}

\begin{abstract}
The role of arsenic trioxide $\left(\mathrm{As}_{2} \mathrm{O}_{3}\right)$ in inhibiting immune rejection and prolonging islet allograft survival has been identified in islet allotransplantation. This study aims to explore the role of $\mathrm{As}_{2} \mathrm{O}_{3}$ in islet xenotransplantation and the action mechanism. The streptozotocin (STZ) was used in C57BL/6 mice to induce the type 1 diabetes mellitus (T1DM) for xenotransplantation models establishment. Donor islets were isolated by digesting. The flow cytometry (FCM) was used to analyze lymphocyte types. The blood sugar level was detected by using intraperitoneal glucose tolerance test (IPGT). The serum level of cytokines was determined by the enzyme-linked immunosorbent assay (ELIZA). The cell proliferation was measured by MTT assay. The mRNA levels were quantified with qRT-PCR. $\mathrm{As}_{2} \mathrm{O}_{3}$ prolonged the survival of the recipient mice but had no influence on body weight. $\mathrm{As}_{2} \mathrm{O}_{3}$ protected the function of xenograft in insulin secretion and suppressed immune rejection of recipient. $\mathrm{As}_{2} \mathrm{O}_{3}$ inhibited proliferation of T lymphocyte and increased the proportion of Foxp3 ${ }^{+}$regulatory T cells in recipient mice. $\mathrm{As}_{2} \mathrm{O}_{3}$ inhibited activation and promoted clonal anergy of $\mathrm{T}$ lymphocyte. $\mathrm{As}_{2} \mathrm{O}_{3}$ decreased total number of $\mathrm{B}$ cells and reduced partial antibody levels in recipient mice. $\mathrm{As}_{2} \mathrm{O}_{3}$ and leflunomide showed a synergistic effect in suppressing islet xenotransplant rejection. $\mathrm{As}_{2} \mathrm{O}_{3}$ prolongs islet xenograft survival by inhibiting cellular immune response, and increasing Foxp ${ }^{+}$regulatory $\mathrm{T}$ cells, while decreasing partial antibody levels in serum.
\end{abstract}

\section{Introduction}

The type 1 diabetes mellitus (T1DM), also called insulin-dependent or juvenile diabetes, begins with insulin-producing beta cells attacked by autoimmune and subsequent deficiency of insulin, leading to increased glucose content in blood and urine ${ }^{1}$. Hyperglycemia caused by deficiency of insulin causes many complications in various tissues and organs, such as eyes, heart, blood vessels, and nerves ${ }^{2}$. Due to the absolute lack of

Correspondence: Q-I. Ma (mu42963274@163.com) or Z

q. Qi (trngjear6428@163.com) or B-h. Zhao (benhuazhao@163.com)

'State Key Laboratory of Molecular Vaccinology and Molecular Diagnostics,

Xiamen University, 361005 Xiamen, Fujian, China

${ }^{2}$ Department of Neurology, The First Affiliated Hospital of Xiamen University, 361005 Xiamen, Fujian, China

Full list of author information is available at the end of the article Edited by $\mathrm{H}-\mathrm{U}$. Simon. endogenous insulin in T1DM, the continuous and indefinite supplement of exogenous insulin is indispensable. The main clinical treatment of diabetes mellitus includes insulin injection, oral hypoglycemic agents, combined with healthy life style, but these therapies often result in increased risk of disorder of glucose metabolism ${ }^{3}$. and hypoglycemia ${ }^{4}$. Other than exogenous substances, islet transplantation is a promising therapy for T1DM through regulating glycometabolism accordingly by blood glucose level of the organism ${ }^{5}$.

Recently, clinical islet transplantation for diabetes has been focused on and it has achieved success as insulin independence rates up to five years after transplant, with minimal complications ${ }^{6}$. Islet transplantation shows lots of advantages on simple operation, low immunosuppression, and less complication ${ }^{7}$, exhibiting great potential in 
T1DM treatment. Nevertheless, the widely use of islet transplantation is largely hampered by immune rejection and short supply of donors, especially for islet allotransplantation $^{8}$. Islet xenotransplantation from the porcine pancreata was performed for the first time ${ }^{9}$, which initiated the journey of islet xenotransplantation. A consensus statement was published by the International Xenotransplantation Association (IXA) in 2009 to undertake clinical trials of porcine islet products for T1DM treatment ${ }^{10}$, and it was updated recently ${ }^{11}$, forecasting the promising clinical application of islet xenotransplantation in the near future. Islet xenotransplantation can be an attractive alternative to overcome the problem of donor shortage, but still with barriers of immune rejection, in which immunosuppressive agents are urgently needed ${ }^{12}$.

As a traditional drug for various disorders, arsenic trioxide $\left(\mathrm{As}_{2} \mathrm{O}_{3}\right)$ was approved by the US Food and Drug Administration (FDA) for relapsed or refractory acute promyelocytic leukemia (APL) in 2000, after randomized clinical trials ${ }^{13} \cdot \mathrm{As}_{2} \mathrm{O}_{3}$ also was reported to alleviate the allograft rejection in mice, and it inhibited allografts rejection mediated by alloreactive CD8(+) Tm cells in the mouse heart transplantation model, serving as an antirejection agent ${ }^{14,15}$. In the previous study, we found that $\mathrm{As}_{2} \mathrm{O}_{3}$ prolonged islet allograft survival and combination of $\mathrm{As}_{2} \mathrm{O}_{3}$ with rapamycin showed a synergistic effect in repressing islet allotransplant rejection and inducing sustained transplant tolerance in mice ${ }^{16}$. These findings suggested that $\mathrm{As}_{2} \mathrm{O}_{3}$ is a promising and crucial immunosuppressive agent in islet allotransplant. In consideration of the limitation of islet allotransplant for donor shortage, we undertook the islet xenotransplantation from rat to mouse and explored the role and clinical values of $\mathrm{As}_{2} \mathrm{O}_{3}$ in islet xenotransplantation.

\section{Materials and methods}

\section{Animals}

The specific-pathogen-free (SPF) female Lewis rats (weight 180-200 g, 8-12 weeks old) purchased from the Beijing Vital River Laboratory Animal Technology Co. Ltd. (Beijing, China) were used as donors; SPF female C57b/6 (H-2b) mice (weight 18-20 g, 8-12 weeks old) purchased from the Slac Laboratory Animal Co. Ltd. (Shanghai, China) were used as recipients. All the animal experiments were approved by the Ethics Committee of the Xiamen University, and performed according to the guidelines of the Institutional Animal Care and Use Committee (IACUC).

\section{Islet isolation}

Donor islets were isolated by a digestion method that described previously ${ }^{17}$. The pancreas was perfused with 1 $\mathrm{mg} / \mathrm{ml}$ collagenase $\mathrm{P}$ (Roche, Basel, Switzerland) and digested at $38^{\circ} \mathrm{C}$ for $20 \mathrm{~min}$. After digestion, the pancreatic tissue was mixed with Histopaque-10771 and Histopaque-11191 (Sigma-Aldrich), and the purified islet cells were obtained by density gradient centrifugation.

\section{Flow cytometry (FCM)}

Islet cells were dissociated into single cells by $0.25 \%$ trypsin-EDTA and $25 \mathrm{U} / \mathrm{ml}$ DNase I at $37^{\circ} \mathrm{C}$ for $15 \mathrm{~min}$, and purified lymphocytes were acquired from the spleen and inguinal lymph node after treated with the red blood cell lysis buffer and filtration. Cells were stained with monoclonal antibodies (anti-annexin $\mathrm{V}$ and anti-7-AAD antibodies, BD PharMingen, San Diego, CA; anti-CD4 ${ }^{+}$, anti-CD8 ${ }^{+}$, and anti-Foxp $3^{+}$antibodies, eBioscience, San Diego,CA). The results were analyzed by the BD FACScanTM system (Partec Co., Munster, Germany) and FlowJo software (Tree Star Inc., Ashland, OR).

\section{Diabetes induction and islet xenotransplantation}

Recipient mice were treated with $180 \mathrm{mg} / \mathrm{kg}$ streptozotocin (STZ) intra-peritoneally (IP) to induce the diabetes model ${ }^{18}$. After three days, mice with a blood glucose level higher than $16.7 \mathrm{mM}$ in two consecutive days were used for transplantation. And 400 islets were transplanted into the recipient mice under the kidney capsule and grafts with blood glucose levels less than $8.4 \mathrm{mM}$ in two consecutive days were considered the successful transplantation. And it was judged as graft rejection when blood glucose level was higher than $1.1 \mathrm{mM}$ in two consecutive days.

\section{Groups and treatments}

The recipient mice were divided into four groups $(n=8$ in each group): $\mathrm{As}_{2} \mathrm{O}_{3}$ group (As, $5 \mathrm{mg} / \mathrm{kg} \mathrm{As}_{2} \mathrm{O}_{3}$ twice per day, IP), leflunomide group (Lef, $20 \mathrm{mg} / \mathrm{kg}$ Lef daily, IP), combined group (Lef + As, $5 \mathrm{mg} / \mathrm{kg} \mathrm{As}_{2} \mathrm{O}_{3}$ twice per day and $20 \mathrm{mg} / \mathrm{kg}$ Lef daily, IP) and control group (normal saline, IP).

\section{Intraperitoneal glucose tolerance test (IPGTT)}

The IPGTT was carried out in recipient mice at five days after transplantation. The mice were fasted for $12-14 \mathrm{~h}$ and then intra-peritoneally injected with blood glucose $(1 \mathrm{mg} / \mathrm{g})$. And the blood glucose levels in tail vein were detected at $0,5,10,15,30,60$, and $120 \mathrm{~min}$ after injection.

\section{Histopathology}

At the 7th day after transplantation, each islet graft and the homolateral kidney were fixed in a zinc fixative (Biolegend, San Diego, CA) and embedded with paraffin, for cutting into $5-\mu \mathrm{m}$ sections and staining with hematoxylin-eosin (H\&E) or biotin-conjugated rabbit antimouse insulin monoclonal antibodies (Cell Signaling Technology Inc., Beverly, MA). The microscopy (Motic 
BA310; Motic Co. Ltd., Hong Kong, China) was used for image capturing. All the results were assessed in a doubleblind manner.

\section{Quantitative real-time PCR (qRT-PCR)}

Total RNA of tissues from islet graft and the homolateral kidney was extracted with trizol reagent (Invitrogen) and the cDNA was synthesized by reverse transcription with a Reverse Transcription Kit (Applied Biosystems). The expression of related genes was quantified by qRT-PCR with SYBR Select Master Mix (Applied Biosystems) on an ABI 7300-fast Real-Time PCR system. With $\beta$-actin served as control. Primers were designed and synthesized by the Sangon Biotech (Shanghai, China) and the primer sequences were showed. $\beta$-actin: forward $5^{\prime}-$ CATCCGTAAAGACCTCTATGCCAAC- $3^{\prime}$ and reverse 5'-ATGGAGCCACCGATCCACA-3'; IL-2: forward 5'GGAGCAGCTGTTGATGGACCTAC-3' and reverse $5^{\prime}$ AATCCAGAACATGCCGCAGAG- $3^{\prime}$; interferon (IFN)- $\gamma$ : forward $5^{\prime}$-CGGCACAGTCATTGAAAGCCTA- $3^{\prime}$ and reverse 5 '-GTTGCTGATGGCCTGATTGTC-3'; TGF- $\beta$ : forward $5^{\prime}$-GACCAGCTGGACAACATACTGCTAA- ${ }^{\prime}$ and reverse 5'-GATAAGGCTTGGCAACCCAAGTAA-3'; IL-4: forward 5'-CAGCTCTGCTGGCGAAAGTG-3' and reverse 5 '-TCGTCTGAAGGCAGAGTCAGGA-3'. The relative expression was calculated by the $2^{-\Delta \Delta \mathrm{Ct}}$ method.

\section{Mixed lymphocyte reaction (MLR) and MTT assay}

$\mathrm{T}$ lymphocytes were isolated from spleen of the recipient mice by using nylon wool columns (Wako, Osaka, Japan) at the 10th day after transplantation and served as responder cells. Spleen cells derived from Lewis rats were pretreated with mitomycin $\mathrm{C}$ and served as stimulator cells. MLR assays were performed as previously described $^{19}$. After $72 \mathrm{~h}$ of culture, the cell proliferation was measured with a MTT cell proliferation assay kit (Cayman). Then $10 \mu \mathrm{MTT}$ was added into each well and maintained for $4 \mathrm{~h}$ at $37^{\circ} \mathrm{C}$. After the culture medium was removed, $100 \mu \mathrm{LMSO}$ was added and the sample was slowly agitated for $10 \mathrm{~min}$ for crystals dissolution at room temperature. The absorbance at $450 / 630 \mathrm{~nm}$ was measured on the microplate reader (Bio-Rad).

\section{ELIZA}

Recipient mouse serum and MLR supernatants after 72 $\mathrm{h}$ of incubation were collected, and the serum level of IFN- $\gamma$, IL-2, IL-4, and TGF- $\beta$ in recipient mice was determined with the enzyme-linked immunosorbent assay (ELIZA) kits (NeoBioscience Technology Co. Ltd., Beijing, China) according to the manufacturer's instructions.

\section{Western blot}

The expression of phosphorylated p38 (p-p38) in T lymphocytes was analyzed by western blot. For protein extraction, $\mathrm{T}$ lymphocytes from the recipient mice were treated with RIPA lysis buffer (Beyotime), and the concentration of protein was assessed by using a BCA protein assay kit (Beyotime). Total protein was separated with 12\% SDS-PAGE and transferred onto the polyvinylidene difluoride (PVDF) membrane (Bio-Rad). The membrane was then blocked with tris-buffered saline tween-20 (TBST) containing 5\% nonfat milk for $1 \mathrm{~h}$ at $\mathrm{RT}$, and then incubated with the following primary antibodies: anti-p-p38 antibody (Abcam, 1:200), anti- $\beta$ actin antibody (Abcam, 1:3000) for $1 \mathrm{~h}$ at RT. The membrane was then incubated with HRP-bounded secondary antibodies for $1 \mathrm{~h}$ at RT and the proteins were visualized with an ECL Plus Western Blotting Substrate (Thermo Fisher). $\beta$-actin served as control to evaluate the relative expression.

\section{Statistical analysis}

The median survival time (MST) of the animals was analyzed with the Kaplan-Meier method. Data in different groups were analyzed by the one-way analysis of variance (one-way ANOVA) and represented as means \pm standard deviation (SD). Difference between groups was analyzed with Student's $t$-test. All analyses were performed with the Graphpad Prism (GraphPad, Inc., CA) software.

\section{Results}

\section{$\mathrm{As}_{2} \mathrm{O}_{3}$ prolonged xenografts survival and protected the} function of insulin secretion

After xenotransplantation, $\mathrm{As}_{2} \mathrm{O}_{3}$ (As) significantly prolonged MST of xenograft to 13 days, which was similar to the Lef group but longer than the control group (8 days); the survival time in Lef + As group (29 days) was markedly longer than that of control group, with significant difference $(P<0.01)$ (Fig. 1a). The insulin secretion condition was measured by the immunohistochemistry assay, and the insulin secretion in As and Lef + As group was better than control group, and Lef + As group showed the best insulin secretion condition (Fig. 1b). Lose weight is the main clinical symptom of T1DM, and the weight monitoring was conducted in mice before and after transplantation. It showed that the body weight of mice increased when the blood sugar maintained at the normal levels, while it declined with increased blood sugar; but no difference was found in increase trend of body weight among four groups (Fig. 1c), suggesting that body weight was little influenced by different drug treatments. The $2 \mathrm{~h}$ IGPTT was performed in recipient mice treated with different drugs at day 5 after transplantation, and the blood glucose levels were recorded (Fig. 1d), and the area under the curve (AUC) was statistically analyzed (Fig. 1e); and it showed that the function of islets in As, Lef, and Lef + As group 


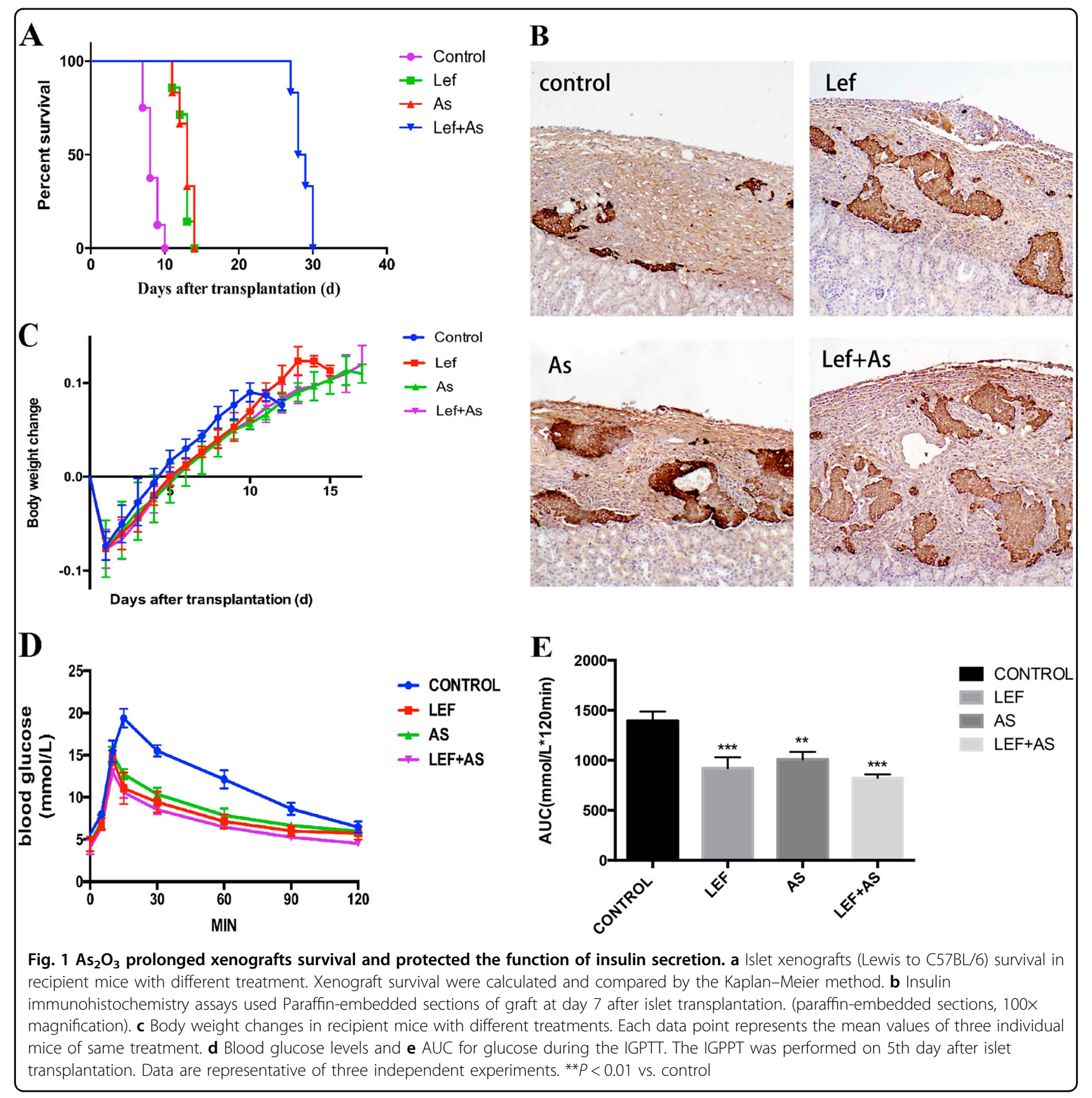

was better than that of control group, and the best function of islets was observed in the Lef + As group.

\section{$\mathrm{As}_{2} \mathrm{O}_{3}$ suppressed immune rejection of recipient to xenograft}

At the 7th day after transplantation, the conditions of tissue destruction and inflammatory infiltration were evaluated by H\&E staining (Fig. 2a), with a pathological score (rank number). Recipient mice in the Lef + As group showed the highest pathological score, and the scores in Lef and As group were all significantly higher than that in control group, which had the lowest pathological score (Fig. 2b). Tissues from islet graft were taken and the immune factors associated with immune rejection were quantified with qRT-PCR. Compared with control, the levels of IL-2, IL-4, and IFN- $\gamma$ were obviously decreased in As and Lef + As group (Fig. 2c), suggesting that the immune rejection was suppressed by $\mathrm{As}_{2} \mathrm{O}_{3}$. The result of qRT-PCR was also supported by the immunohistochemistry that showed the infiltration of $\mathrm{CD} 4^{+}$and $\mathrm{CD}^{+} \mathrm{T}$ lymphocytes. The infiltration of $\mathrm{CD} 4^{+}$and $\mathrm{CD}^{+}{ }^{+} \mathrm{T}$ cells was 


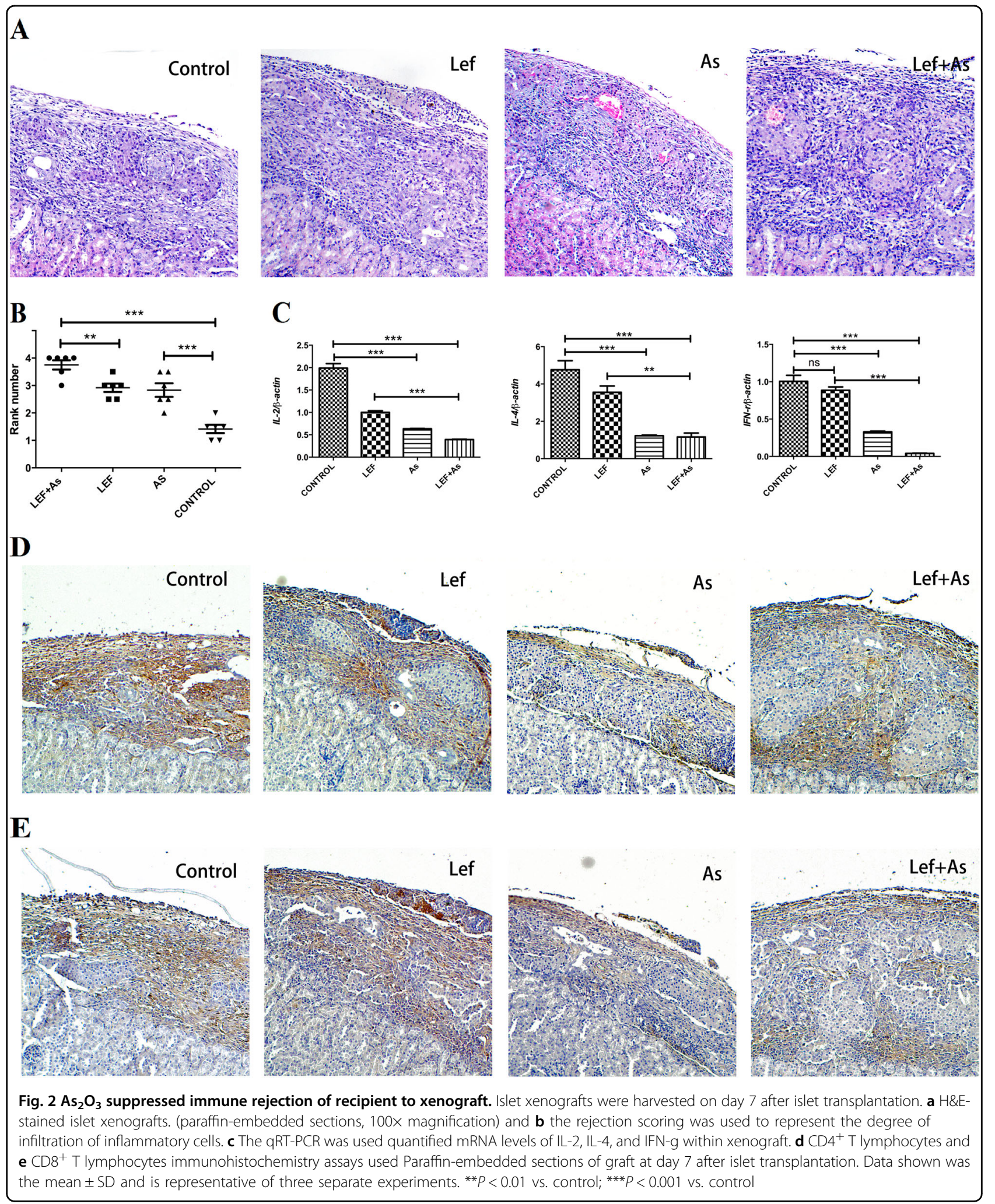

lower in As and Lef + As group than that of control group, and it was lower in Lef + As group than that in Lef group (Figs. 2d, e).

\section{$\mathrm{As}_{2} \mathrm{O}_{3}$ inhibited proliferation of $\mathrm{T}$ lymphocyte}

At the 7th day after transplantation, cell typing of lymphocytes in the spleen and lymph node cells was 

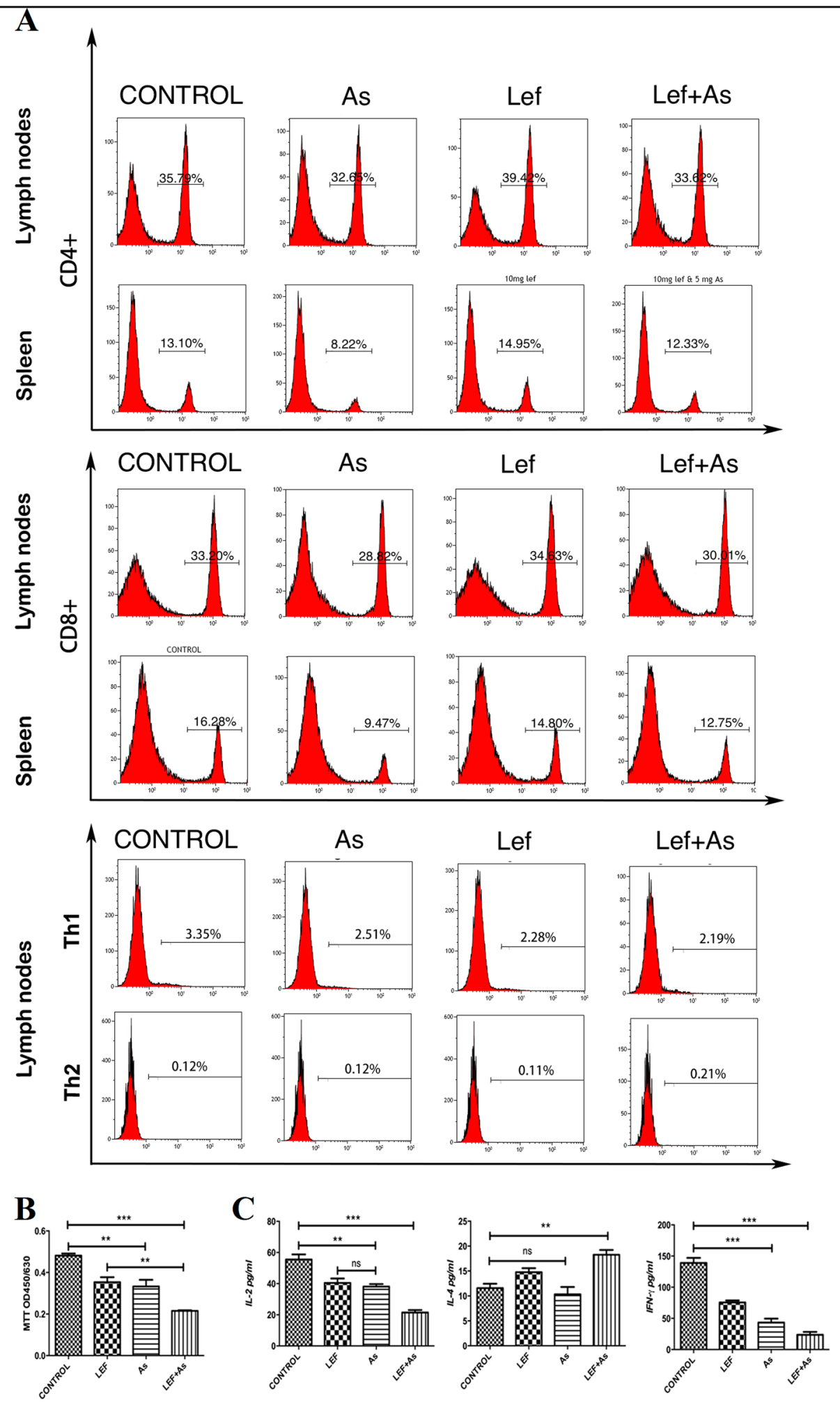

Fig. $3 \mathrm{As}_{2} \mathrm{O}_{3}$ inhibited proliferation of T lymphocyte. a The cumulative data of the proportion of $\mathrm{CD}^{+}{ }^{+}$and $\mathrm{CD} 8^{+} \mathrm{T}$ cells, and Th1 and Th2 cells in the spleen and lymph node cells of recipients were analyzed by flow cytometry on day 7 after transplantation. $\mathbf{b}$ Seven days after transplantation, MTT were used to examine the proliferative response of recipient (C57BL/6) spleen T cells to donor-type spleen cell (Lewis). c ELIZAs were used to test the concentrations of cytokine in the recipient serum collect on day 7 post transplantation. Each group was tested in quadruplicate wells. The shown percentages are only indicative of the representative data of three separate experiments. ${ }^{* *} P<0.01 \mathrm{vs}$. control; ${ }^{* * *} P<0.001$ vs. control 


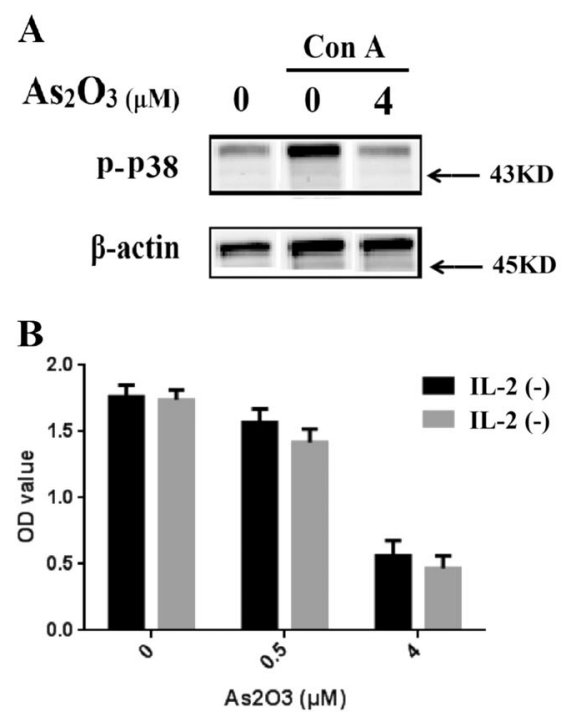

Fig. $4 \mathrm{As}_{2} \mathrm{O}_{3}$ inhibited activation and promoted clonal anergy of T lymphocyte. a After induced by Concanavalin $\mathrm{A}(\mathrm{Con} \mathrm{A}, 5 \mu \mathrm{g} / \mathrm{ml})$ and treated with $\mathrm{As}_{2} \mathrm{O}_{3}$ at different concentrations for $24 \mathrm{~h}$, the expression of phosphorylated p38 (p-p38) was determined by western blot. $\mathbf{b}$ With exogenous IL-2 added, T lymphocytes from the recipient mice were treated with Con A (5 $\mu \mathrm{g} / \mathrm{ml})$ and $\mathrm{As}_{2} \mathrm{O}_{3}$ at different concentrations for $48 \mathrm{~h}$, and the proliferation activity was examined with MTT

conducted with FCM. Compared with control group, $\mathrm{As}_{2} \mathrm{O}_{3}$ reduced the proportion of $\mathrm{CD}^{+}$and $\mathrm{CD}^{+}{ }^{+} \mathrm{T}$ cells, regardless of whether Lef was used, and their percentage in Lef group was slightly higher than that of control group; the proportion of Th1 cells in As and Lef + As group was lower than that of control group, and the proportion of Th2 cells in groups was too low to compare with each other (Fig. 3a). The proliferation activity of lymphocytes was determined by MTT assay and the levels of serum cytokines derived from Th1 and Th2 cells were detected by ELIZA. Compared with control group, the proliferation activity of lymphocytes was lower in As and Lef + As groups, and the Lef + As group showed the lowest proliferation activity (Fig. 3b). Compared with control group, the levels of cytokines derived from Th1 cells (IL-2 and IFN- $\gamma$ ) were lower in As and Lef + As groups, which was the lowest in combination group. The levels of cytokines derived from Th2 cells (IL-4) in combination group were higher than that in control, while no significant difference was noted between As and control group (Fig. 3c).

\section{$\mathrm{As}_{2} \mathrm{O}_{3}$ inhibited activation and promoted clonal anergy of T lymphocyte}

In our previous study, we identified that $\mathrm{As}_{2} \mathrm{O}_{3}$ combined with rapamycin suppressed $\mathrm{T}$ cell activation via inhibiting p38-MAPK signaling pathways ${ }^{16}$. Here, to evaluation the influence of $\mathrm{As}_{2} \mathrm{O}_{3}$ on $\mathrm{T}$ lymphocyte activation, $\mathrm{T}$ lymphocyte was induced by Concanavalin A (Con A, $5 \mu \mathrm{g} / \mathrm{ml}$ ) for proliferation, and simultaneously treated with $\mathrm{As}_{2} \mathrm{O}_{3}$ at different concentrations for $24 \mathrm{~h}$. And the expression of $\mathrm{p}$ - p38 was determined. It revealed that $\mathrm{As}_{2} \mathrm{O}_{3}$ inhibited the phosphorylation of p38 in $\mathrm{T}$ lymphocyte, with a dosagedependent method (Fig. 4a), suggesting the inhibitory effect of $\mathrm{As}_{2} \mathrm{O}_{3}$ on $\mathrm{T}$ lymphocyte activation. Besides, Interleukin-2 (IL-2) is a cytokine that stimulates proliferation and differentiation of $\mathrm{T}$ lymphocytes, and it induces the secretion of IFN- $\gamma$ by T lymphocytes as well. With exogenous IL-2 added, $\mathrm{T}$ lymphocytes from the recipient mice were treated with Con $\mathrm{A}(5 \mu \mathrm{g} / \mathrm{ml})$ and $\mathrm{As}_{2} \mathrm{O}_{3}$ at different concentrations for $48 \mathrm{~h}$. It showed that exogenous IL-2 could not reverse the proliferation suppression induced by $\mathrm{As}_{2} \mathrm{O}_{3}$, implying the role of $\mathrm{As}_{2} \mathrm{O}_{3}$ in promoting clonal anergy of $\mathrm{T}$ lymphocyte (Fig. 4b).

\section{$\mathrm{As}_{2} \mathrm{O}_{3}$ increased the proportion of Foxp ${ }^{+}$regulatory $\mathrm{T}$ cells in recipient mice}

The detection of $\mathrm{CD}^{+}{ }^{+}$Foxp $^{+}{ }^{+} \mathrm{T}$ regulatory (Treg) cells in lymph nodes indicated that the percentage of Treg cells was higher in As and Lef + As group than that in control group, and the combination group showed the highest Treg cells proportion (Fig. 5a). The Foxp $3^{+}$expression was higher in As and Lef + As group than that in control group, and it was highest in the combination group (Fig. 5b). Similarly, the expression of TGF- $\beta$ was lowest in control and highest in the combination group (Fig. 5c).

\section{$\mathrm{As}_{2} \mathrm{O}_{3}$ decreased total number of $\mathrm{B}$ cells and reduced partial antibody levels in recipient mice}

The proportion of CD19 $9^{+} \mathrm{B}$ cells in spleen of recipient mice was examined, and it showed that the percentage of 

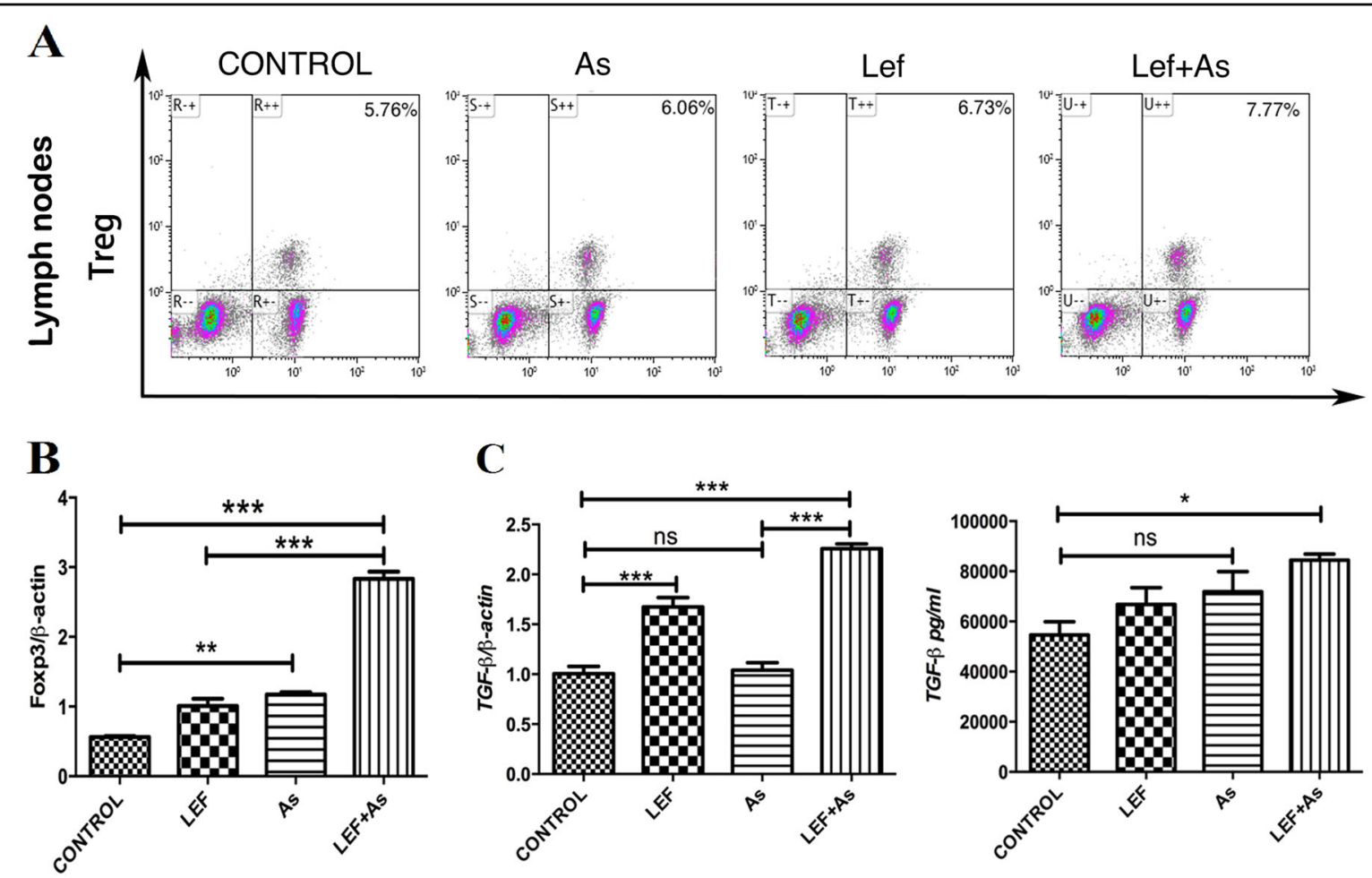

Fig. $5 \mathrm{As}_{2} \mathrm{O}_{3}$ increased the proportion of Foxp3 ${ }^{+}$regulatory T cells in recipient mice. a Proportions of splenic and lymph node $\mathrm{CD}^{+}$Foxp3 ${ }^{+}$ Treg cells were analyzed by flow cytometry at day 7 after transplantation ( $n=3$ mice per group). b Graft TGF-beta and Foxp3 mRNA levels were quantified by qRT-PCR, and $\mathbf{c}$ recipient mouse sera TGF-beta concentrations were quantified by ELIZA. ELIZAs were used to test the concentrations of TGF-beta in the recipient serum collect on day 7 after transplantation. Each group was tested in quadruplicate wells. The shown percentages are only indicative of the representative data of three separate experiments. ${ }^{*} P<0.05$ vs. control; ${ }^{* *} P<0.01$ vs. control; ${ }^{* *} P<0.001$ vs. control

$\mathrm{CD} 19^{+} \mathrm{B}$ cells in As and Lef + As group was significantly higher than that of control group, and it was the highest in As group (Fig. 6a). The total number of lymphocytes and B cells in spleen in As and Lef + As groups was lower than that of control, and the total number of lymphocytes was the lowest in As group and the B cells were the least in combination group (Fig. 6b). The levels of serum antibodies related to immune rejection were detected. The levels of IgM and IgG2a were lower in As and Lef + As groups, and the combination group had the lowest antibody levels, while IgG levels in As group was not lower than that in control group (Fig. 6c).

\section{Discussion}

With the Edmonton protocol for islet transplantation proposed in the New England Journal of Medicine ${ }^{20}$, islet xenotransplantation has become a popular research topic once more. Islet transplantation involves in transplantation of cell clusters, with the feature of none angiogenic cerebral immune rejection from donor and inability of single donor transplantation, which enables islet xenotransplantation to be a cross hot issue between xenotransplantation and islet transplantation ${ }^{21,}{ }^{22}$. Nevertheless, the mechanism of refection in islet xenotransplantation is extremely complicated and no successful immune tolerance induction in xenograft has been reported yet. In this study, $\mathrm{As}_{2} \mathrm{O}_{3}$ was proved to be an effective immunosuppressant that could be used alone in islet xenotransplantation from rat to mouse. It prolonged islet xenograft survival and protected islet transplant from inflammation and $\mathrm{T}$ cells infiltration to maintain the normal shape, structure, and function of insulin secretion. In addition, $\mathrm{As}_{2} \mathrm{O}_{3}$ had no influence on body weight of recipent mice at the dose of $5 \mathrm{mg} / \mathrm{kg} / \mathrm{d}$.

Rejection of islet xenografts is an immune response that closely associated with $\mathrm{T}$ cells ${ }^{23}$, which can be divided into variety of subpopulations. Among them are the $\mathrm{CD} 8^{+}$and $\mathrm{CD} 4^{+} \mathrm{T}$ cells, and they are the predominant $\mathrm{T}$ cells for graft-infiltrting in graft rejection ${ }^{24}$. It has been revealed that activated $\mathrm{CD} 8^{+} \mathrm{T}$ cells infiltrated cardiac allografts continuously within $72 \mathrm{~h}$ after transplantation, in which they promoted graft rejection via producing high levels of proinflammatory IFN $-\gamma^{25}$, and the production of IFN $-\gamma$ by $\mathrm{CD}^{+} \mathrm{T}$ cells has been speculated to be the rate-limiting step in process of allograft rejection ${ }^{26}$. And the $\mathrm{CD} 4^{+}$ $\mathrm{T}$ cells has been demonstrated to be necessary and sufficient for cardiac allograft rejection, in which the intact host major histocompatibility complex (MHC) Class II is 


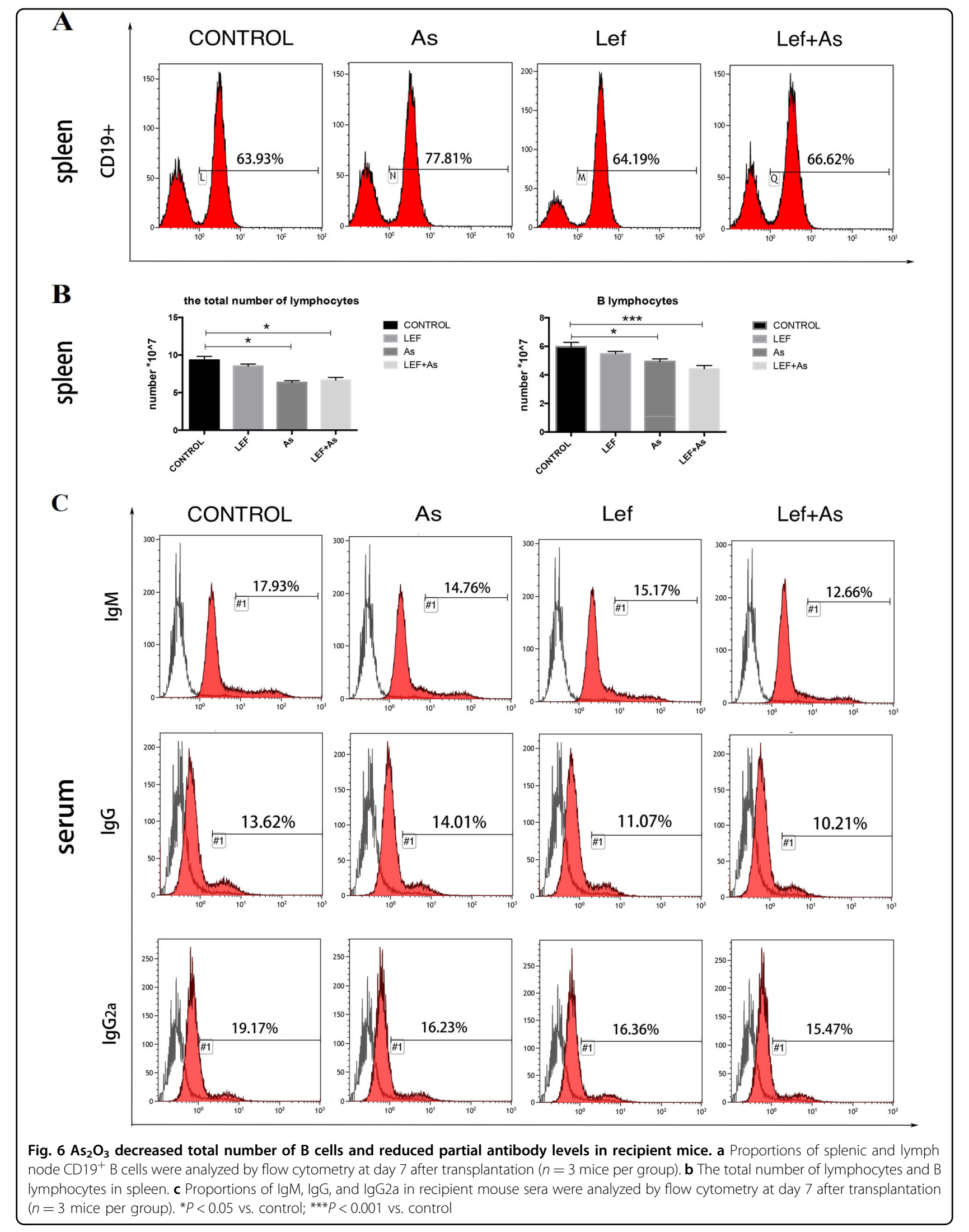


required ${ }^{27}$. Besides, the protective potential of $\mathrm{CD} 4^{+}$ CD $25^{+}$Foxp $^{+}$Treg cells has been identified in xenotransplantation ${ }^{28}$. According to the findings of the present study, we can believe that $\mathrm{As}_{2} \mathrm{O}_{3}$ significantly inhibited the cellular immunity level by reducing the proportion of $\mathrm{CD}^{+}$and $\mathrm{CD}^{+}{ }^{+}$cells, and decreasing the proportion of Th1 cells in $\mathrm{CD}_{4}^{+} \mathrm{T}$ cells, and elevating the proportion of $\mathrm{CD}_{4}^{+}$Foxp3 $^{+}$Treg cells. $\mathrm{As}_{2} \mathrm{O}_{3}$ also decreased the absolute number of $\mathrm{B}$ cells in spleen and lessened the level of IgM and IgG2a, but it had no effect on levels of IgG, which plays key role in humoral immunity. And the levels of humoral immunity didn't differ significantly among different treatment groups, indicating that the influence of $\mathrm{As}_{2} \mathrm{O}_{3}$ on humoral immunity should be further studied.

Combination of $\mathrm{As}_{2} \mathrm{O}_{3}$ and Lef was more effective than individual of the both in prolonging islet xenograft survival and in various index in vivo and in vitro, suggesting the synergistic effect between $\mathrm{As}_{2} \mathrm{O}_{3}$ and Lef in immunosuppressive process. As a low molecular weight immunosuppressive drug, Lef inhibited the activity of dihydroorotate dehydrogenase and protein tyrosine kinase, which are the vital participants in immune reaction ${ }^{29}$. However, longterm of transplantation tolerance was not achieved by combination of $\mathrm{As}_{2} \mathrm{O}_{3}$ and Lef, which may result from the unsatisfactory inhibitory effect of Lef on B cells. Therefore, combination therapy that suppresses B cells effectively should be proposed to realize better immune tolerance between recipent mice and transplantaiton. In addition, influence of $\mathrm{As}_{2} \mathrm{O}_{3}$ on Th2 cells was not determinted in our study, which plays crucial role in humoral immunity and activation of $\mathrm{B}$ cells $^{30}$. We speculated that it may be unsuitable for Th2 cells to be detected at day 7 after transplantation, at which the Th2 may have not reach a peak. In the future research, the variation trend and role of Th2 in islet transplantation may be explored at different time points to get more information.

In conclusion, $\mathrm{As}_{2} \mathrm{O}_{3}$ prolongs islet xenograft survival by inhibiting cellular immune response, increasing Foxp $3^{+}$regulatory $\mathrm{T}$ cells and decreasing partial antibody levels in serum, and it showed a synergistic effect with leflunomide in immunosuppressive effect. This study confirmed the pivotal role and great clinical values of $\mathrm{As}_{2} \mathrm{O}_{3}$ in islet xenotransplantation, providing significant theoretical foundation for clinical application of islet xenotransplantation.

\section{Acknowledgements}

This work was support by grants from the National Natural Science Foundation of China (NSFC, 81302546, 81441047,81373086), the Major State Scientific Research Program of China (2012CBA01303), the Xiamen Science and Technology Key program grant (3502Z20100006), and the President Foundation of Xiamen University (20720152012).

\section{Author details}

'State Key Laboratory of Molecular Vaccinology and Molecular Diagnostics, Xiamen University, 361005 Xiamen, Fujian, China. ${ }^{2}$ Department of Neurology,
The First Affiliated Hospital of Xiamen University, 361005 Xiamen, Fujian, China. ${ }^{3}$ Organ Transplantation Institute, Medical College, Xiamen University, 361005 Xiamen, Fujian, China

\section{Conflict of interest}

The authors declare that they have no conflict of interest.

\section{Publisher's note}

Springer Nature remains neutral with regard to jurisdictional claims in published maps and institutional affiliations.

Received: 30 November 2017 Revised: 10 February 2018 Accepted: 23 February 2018

Published online: 14 March 2018

\section{References}

1. Eisenbarth, G. S. Prevention of type 1 A diabetes mellitus. Endocr. Pract. 18, 745-749 (2012).

2. Fathallah, N., Slim, R., Larif, S., Hmouda, H. \& Ben Salem, C. Drug-induced hyperglycaemia and diabetes. Drug Saf. 38, 1153-1168 (2015).

3. Takimoto, R. Disorder of glucose metabolism (hypoglycemia, hyperglycemia). Nihon Rinsho 73(Suppl 2), 436-440 (2015).

4. Savas-Erdeve, S. et al. An uncommon cause of hypoglycemia: insulin autoimmune syndrome. Horm. Res. Paediatr. 82, 278-282 (2014).

5. Shapiro, A. M., Ryan, E. A. \& Lakey, J. R. Pancreatic islet transplantation in the treatment of diabetes mellitus. Best Pract. Res. Clin. Endocrinol. Metab. 15, 241-264 (2001).

6. Bruni, A., Gala-Lopez, B., Pepper, A. R., Abualhassan, N. S. \& Shapiro, A. J. Islet cell transplantation for the treatment of type 1 diabetes: recent advances and future challenges. Diabetes Metab. Syndr. Obes. 7, 211-223 (2014).

7. Noguchi, H., Yamada, T. \& Tanaka, K. Islet transplantation. Nihon Rinsho 69, 2209-2213 (2011).

8. Ahearn, A. J., Parekh, J. R. \& Posselt, A. M. Islet transplantation for type 1 diabetes: where are we now? Expert Rev. Clin. Immunol. 11, 59-68 (2015).

9. Groth, C. G. et al. Transplantation of porcine fetal pancreas to diabetic patients. Lancet 344, 1402-1404 (1994).

10. Hering, B. J. et al. The International Xenotransplantation Association consensus statement on conditions for undertaking clinical trials of porcine islet products in type 1 diabetes--executive summary. Xenotransplantation 16, 196-202 (2009).

11. Hering, B. J. et al. First update of the International Xenotransplantation Association consensus statement on conditions for undertaking clinical trials of porcine islet products in type 1 diabetes--executive summary. Xenotransplantation 23, 3-13 (2016).

12. Matsumoto, S., Tomiya, M. \& Sawamoto, O. Current status and future of clinical islet xenotransplantation. J. Diabetes 8, 483-493 (2016).

13. Antman, K. H. Introduction: the history of arsenic trioxide in cancer therapy. Oncologist 6(Suppl 2), 1-2 (2001).

14. Yan, S. et al. Arsenic trioxide attenuated the rejection of major histocompatibility complex fully-mismatched cardiac allografts in mice. Transplant. Proc. 41, 1855-1858 (2009).

15. Zhou, L. \& Liu, Y. Wnt/ß-catenin signalling and podocyte dysfunction in proteinuric kidney disease. Nat. Rev. Nephrol. 11, 535-545 (2015).

16. Gao, C. et al. Arsenic trioxide induces $\mathrm{T}$ cell apoptosis and prolongs islet allograft survival in mice. Transplantation 99, 1796-1806 (2015).

17. Cheng, P. P. et al. Islet transplantation reverses the effects of maternal diabetes on mouse oocytes. Reproduction 141, 417-424 (2011).

18. Peng, Y. et al. Xenoreactive CD4+memory T cells resist inhibition by anti-CD44 $\mathrm{mAb}$ and reject islet grafts via a Th2-dependent pathway. Xenotransplantation 18, 252-261 (2011).

19. Xu, S. et al. Arsenic trioxide combined with co-stimulatory molecule blockade prolongs survival of cardiac allografts in alloantigen-primed mice. Transpl. Immunol. 24, 57-63 (2010).

20. Shapiro, A. M. et al. International trial of the Edmonton protocol for islet transplantation. N. Engl. J. Med. 355, 1318-1330 (2006).

21. Samy, K. P., Martin, B. M., Turgeon, N. A. \& Kirk, A. D. Islet cell xenotransplantation: a serious look toward the clinic. Xenotransplantation 21, 221-229 (2014). 
22. Park, C. G., Bottino, R. \& Hawthorne, W. J. Current status of islet xenotransplantation. Int. J. Surg. 23, 261-266 (2015)

23. Ricordi, C. \& Strom, T. B. Clinical islet transplantation: advances and immunological challenges. Nat. Rev. Immunol. 4, 259-268 (2004).

24. Shin, J. S. et al. Minimizing immunosuppression in islet xenotransplantation. Immunotherapy 6, 419-430 (2014).

25. Schenk, A. D., Nozaki, T., Rabant, M., Valujskikh, A. \& Fairchild, R. L. Donorreactive CD8 memory $T$ cells infiltrate cardiac allografts within 24-h posttransplant in naive recipients. Am. J. Transplant. 8, 1652-1661 (2008).

26. Diamond, A. S. \& Gill, R. G. An essential contribution by IFN-gamma to CD8+T cell-mediated rejection of pancreatic islet allografts. J. Immunol. 165, 247-255 (2000).
27. Plenter, R. J., Grazia, T. J., Doan, A. N., Gill, R. G. \& Pietra, B. A. CD4 T cells mediate cardiac xenograft rejection via host MHC Class II. J. Heart Lung Transplant. 31, 1018-1024 (2012).

28. Muller, Y. D., Ehirchiou, D., Golshayan, D., Buhler, L. H. \& Seebach, J. D. Potential of T-regulatory cells to protect xenografts. Curr. Opin. Organ Transplant. 17, 155-161 (2012)

29. Zhang, L., Qi, Z., Wu, D., Shan, S. \& Ekberg, H. Additive effects of leflunomide and tacrolimus in prevention of islet xenograft rejection. Scand. J. Immunol. 59 255-260 (2004)

30. Buettner, $M$. et al. Predominance of $\mathrm{TH} 2$ cells and plasma cells in polyoma virus nephropathy: a role for humoral immunity? Hum. Pathol. 43, 1453-1462 (2012). 